\title{
Akt Inhibitor MK2206
}

National Cancer Institute

\section{Source}

National Cancer Institute. Akt Inhibitor MK2206. NCI Thesaurus. Code C90581.

An orally bioavailable allosteric inhibitor of the serine/threonine protein kinase Akt (protein kinase B) with potential antineoplastic activity. Akt inhibitor MK2206 binds to and inhibits the activity of Akt in a non-ATP competitive manner, which may result in the inhibition of the PI3K/Akt signaling pathway and tumor cell proliferation and the induction of tumor cell apoptosis. Activation of the PI3K/Akt signaling pathway is frequently associated with tumorigenesis and dysregulated PI3K/Akt signaling may contribute to tumor resistance to a variety of antineoplastic agents. 